\title{
Pengaruh Halte Bus Trans Semarang terhadap Kinerja Lalu Lintas Pada Jalan 2/2 TT (Studi Kasus: Jalan Dokter Wahidin)
}

\author{
Ari Setiawan \\ Dosen Teknik Sipil Universitas Batanghari, Jambi, Indonesia \\ Correspondence email: setiawanari090@gmail.com
}

\begin{abstract}
Abstrak. Bus Trans Semarang merupakan salah satu moda transportasi umum yang diterapkan di Kota Semarang dan diharapkan mampu mengurangi kepadatan dan kemacetan lalu lintas. Pengoperasian Bus Trans Semarang masih menimbulkan beberapa kendala yaitu Halte Bus Trans Semarang tidak dilengkapi teluk bus. Tujuan dari penelitian ini adalah menganalisis pengaruh keberadaan Halte Bus Trans Semarang terhadap kinerja lalu lintas. Metode analisis pengaruh kinerja lalu lintas yang digunakan adalah membandingkan kecepatan, kepadatan, derajat kejenuhan pada lokasi ada halte dengan tanpa halte. Hasil perhitungan pada lokasi dimana ada halte saat Bus Trans Semarang berhenti $(\mathrm{v}=48.353 \mathrm{~km} / \mathrm{jam}, \mathrm{k}=6.669 \mathrm{smp} / \mathrm{km}$ dan $\mathrm{Dj}=0.913)$, ada halte saat Bus Trans Semarang tidak berhenti $(\mathrm{v}=50.617 \mathrm{~km} / \mathrm{jam}, \mathrm{k}=5.575 \mathrm{smp} / \mathrm{km}$ dan $\mathrm{Dj}=0.668)$ dan tanpa halte $(\mathrm{v}=51.555 \mathrm{~km} / \mathrm{jam}, \mathrm{k}$ = $4.117 \mathrm{smp} / \mathrm{km}$ dan $\mathrm{Dj}=0.543)$. Kesimpulan yang diperoleh, keberadaan Halte Bus Trans Semarang dapat menurunkan kinerja lalu lintas diperburuk pada saat Bus Trans Semarang berhenti di halte.
\end{abstract}

Kata Kunci: Bus Trans Semarang, Kinerja Lalu Lintas, Ekivalen Mobil Penumpang, Halte Bus Trans Semarang, Teluk Bus

\section{PENDAHULUAN}

Kota Semarang Sebagai Ibu Kota Provinsi Jawa Tengah merupakan tempat sekaligus pusat kegiatan masyarakat dari aktivitas ekonomi dan sosial. Dampak dari aktivitas masayarakat tersebut dapat menimbulkan pertumbuhan masyarakat di Kota Semarang. Pertumbuhan selama tahun 2015 sebesar 0.65\% dengan jumlah penduduk sebesar 1.595.267 jiwa (Badan Statistik Nasional, 2015). Pertumbuhan penduduk yang meningkat mengakibatkan akan kebutuhan transportasi juga meningkat.

Transportasi yang banyak digunakan penduduk untuk mobilitas adalah kendaraan pribadi. Kendaraan pribadi yang meningkat dapat mengakibatkan kepadatan dan kemacetan lalu lintas, sehingga untuk mengatasi permasalahan tersebut perlu menerapkan transportasi massal. Di Kota Semarang transportasi massal yang sekarang sudah diterapkan adalah Bus Trans Semarang. Pengoperasiannya Bus Trans Semarang masih menimbulkan beberapa kendala yaitu Halte Bus Trans Semarang pada umumnya tidak dilengkapi teluk bus sehingga menggunakan ruas jalan akibatnya lebar jalan semakain kecil sehingga dapat mempengaruhi kinerja lalu lintas tersebut. Oleh karena itu, pokok permasalahan yang perlu dikaji adalah bagaimana pengaruh Halte Bus Trans Semarang terhadap kinerja lalu lintas.

Jalan Dokter Wahidin merupakan jalan dalam kota yang terletak pada Kawasan Candisari dengan tipe jalan 2 lajur 2 arah tidak terbagi. Jalan tersebut termasuk koridor utama Bus Trans Semarang yang menghubungkan pelabuhan dengan pusat kota sehingga mobilitas kendaraan pada jalan tersebut cukup tinggi. Halte Bus Trans Semarang pada jalan tersebut tidak dilengkapi teluk bus. Jalan Dokter Wahidin dapat dilihat pada Gambar 1.

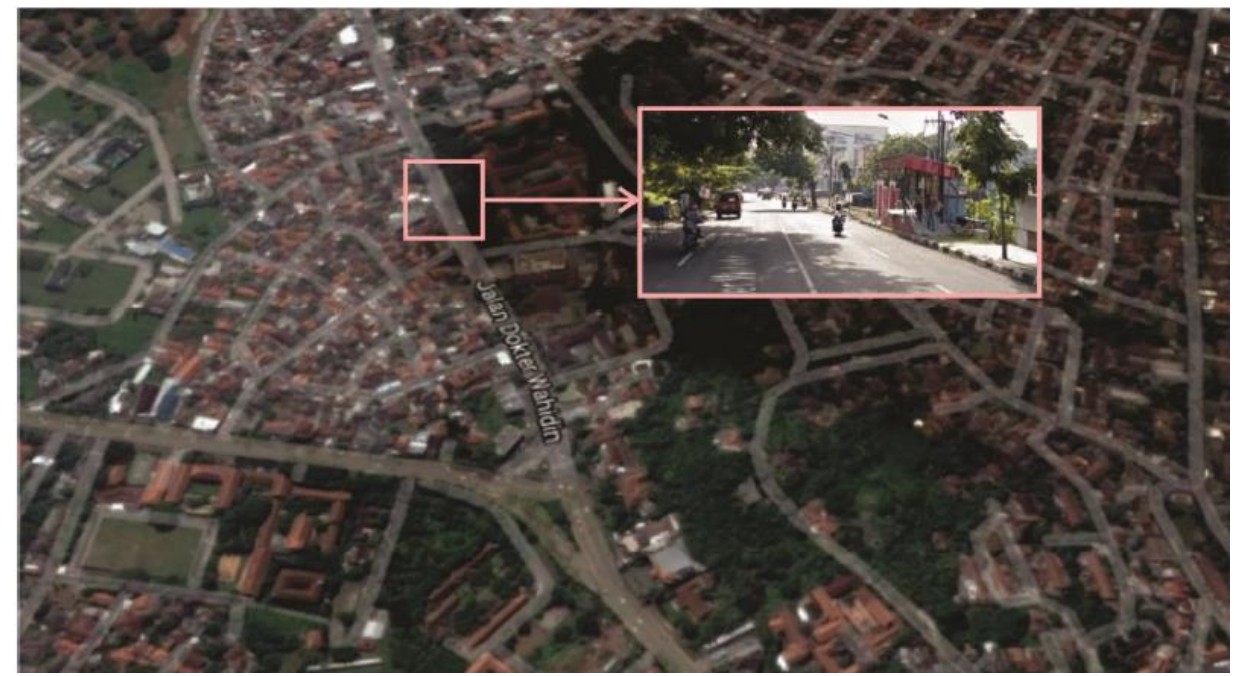

Sumber: Google Maps (2017)

Gambar 1. Jalan Dokter Wahidin 
Batasan penelitian ini adalah sebagai berikut: Halte Bus Trans Semarang tidak dilengkapi teluk bus, nilai ekivalen mobil penumpang (emp) dihitung dengan menggunakan metoda kecepatan, ekivalen mobil penumpang (emp) yang dihitung adalah sepeda motor (SM), kendaraan ringan (KR), angkutan umum dengan ukuran bus kecil (AU), Bus Trans Semarang (BTS) dan truk (TR), lokasi studi Jalan Dokter Wahidin (Kawasan Candisari) dengan tipe jalan 2/2 TT, analisis kinerja dihitung dengan menggunakan metode Uji-t, parameter

Pengaruh kinerja lalu lintas adalah kecepatan rata-rata, kepadatan dan derajat kejenuhan.Tujuan penelitian ini adalah meganalisis pengaruh Halte Bus Trans Semarang terhadap kinerja lalu lintas. Manfaat penelitian ini adalah dapat memberikan gambaran kinerja lalu lintas pada jalan yang dilengkapi Halte Bus Trans Semarang dengan tidak dilengkapi teluk bus, memberikan masukan kepada instansi terkait di bidang lalu lintas jalan berkenaan dengan besaran ekivalen mobil penumpang (emp) terutama pada jalan yang dilengkapi halte bus, memberikan masukan kepada instansi terkait untuk merencanakan dan penempatan halte bus terutama pada bus yang tercampur dengan kendaraan lain.

Kecepatan (v) didefinisikan sebagai suatu laju pergerakan, seperti jarak per satuan waktu, umumnya dalam mil/jam atau kilometer/jam. Karena begitu beragamnya kecepatan individual dalam aliran lalu lintas, maka kita biasanya menggunakan kecepatan rata-rata. Waktu tempuh $t_{1}, t_{2}, t_{3}, \ldots ., t_{n}$ diamati untuk $n$ kendaraan yang melalui suatu ruas jalan sepanjang L (Khisty, 2003).

Kepadatan (k) didefinisikan sebagai jumlah kendaraan yang menempati suatu panjang tertentu dari lajur atau jalan, kemudian dirata - ratakan terhadap waktu, biasanya dinyatakan dengan kendaraan per mil (kend/mil). Perhitungan langsung untuk kepadatan dapat diperoleh dengan melalui foto langsung diudara (Khisty, 2003). Derajat kejenuhan (Dj) didefinisikan sebagai rasio arus terhadap kapasitas (Kementrian Pekerjaan Umum, 2014).

\section{METODE}

Sebelum analisis pengaruh Halte Bus Trans Semarang terhadap kinerja lalu lintas terlebih dahulu dilakukan perhitungan nilai emp. Metode yang digunakan untuk menghitung emp adalah dengan menggunakan metode kecepatan. Metode kecepatan dihitung dengan persamaan regresi linier berganda dengan hubungan antar kecepatan (v) dan arus lalu lintas (q) (Koeswandono, 2007).

Variabel bebas dalam penelitian ini untuk kendaraan mobil berat di bagi menjadi tiga jenis kendaraan yaitu angkutan kota, Bus Trans Semarang dan truk. Koefisien dari regresi yang didapat digunakan untuk perhitungan nilai emp.

Metode yang digunakan untuk menganalisisi pengaruh keberadaan halte Bus Trans Semarang terhadapa kinerja lalu lintas dengan menggunakan uji-t.

Uji-t untuk mengetahui atau membandingkan dua variabel dengan hipotesa sebagai berikut:

$\mathrm{H}_{0}=$ tidak terdapaat perbedaan yang signifikan dari rata-rata sampel.

$\mathrm{H}_{1}=$ terdapaat perbedaan yang signifikan dari rata-rata sampel.

Dengan kriteria pengujian bahwa $\mathrm{H}_{0}$ diterima jika $-\mathrm{t}_{\text {tabel }}<\mathrm{t}_{\text {hitung }}<\mathrm{t}_{\text {tabel. }}$. Sebaliknya $\mathrm{H}_{0}$ ditolak jika $-\mathrm{t}_{\text {hitung }}<-\mathrm{t}_{\text {tabel }}$ atau $t_{\text {hitung }}>\mathrm{t}_{\text {tabel }}$.

Tingkat signifikansi menggunakan $\alpha=5 \%$ (Siregar, 2015). Variabel yang digunakan untuk uji-t adalah kecepatan rata-rata, kepadatan rata-rata dan derajat kejenuhan rata-rata.

\section{HASIL}

Penelitian ini dilakukan untuk mengetahui pengaruh keberadaan Halte Bus Trans Semarang terhadap kinerja lalu lintas. Parameter untuk analisis kinerja lalu lintas adalah kecepatan, kepadatan dan derajat kejenuhan. Dari hasil survei yang dilakukan didapat data arus lalu lintas, kepadatan lalu lintas dan kecepatan lalu lintas. Data kecepatan lalu lintas diambil bersamaan dengan pengambilan data arus lalu lintas dan kepadatan. Hasil pengukuran waktu tempuh untuk segmen jalan sepanjang 50 meter yang kemudian dilakukan perhitungan dengan menggunakan analisis Space Mean Speed. Kecepatan yang didapat dijadikan sebagai $\mathrm{x}_{1}$ untuk kondisi ada halte Bus Trans Semarang berhenti, $\mathrm{x}_{2}$ untuk kondisi ada halte Bus Trans Semarang tidak berhenti, dan $\mathrm{x}_{3}$ untuk kondisi tanpa halte. Jumlah data (n) untuk $\mathrm{x}_{1}$ sebayak 10, untuk $\mathrm{x}_{2}$ sebayak 80 dan untuk $\mathrm{x}_{3}$ sebayak 90. Jumlah total kecepatan $\left(\sum_{i=1}^{n} x_{i}\right)$ untuk $\left(\sum_{i=1}^{10} x_{1}\right)$ sebayak $483.53 \mathrm{~km} / \mathrm{jam}$, untuk $\left(\sum_{i=1}^{80} x_{2}\right)$ sebayak $4049.35 \mathrm{~km} / \mathrm{jam}$ dan untuk $\left(\sum_{i=1}^{90} x_{3}\right)$ sebayak $4639.96 \mathrm{~km} / \mathrm{jam}$. Jumlah total untuk kecepatan yang sudah dikuadratkan $\left(\sum_{i=1}^{n} x_{i}^{2}\right)$ untuk $\left(\sum_{i=1}^{10} x_{1}^{2}\right)$ sebayak $23451.19(\mathrm{~km} / \mathrm{jam})^{2}$, untuk $\left(\sum_{i=1}^{80} x_{2}^{2}\right)$ sebayak $205685.03(\mathrm{~km} / \mathrm{jam})^{2}$ dan untuk $\left(\sum_{i=1}^{90} x_{3}^{2}\right)$ sebayak $239909.00(\mathrm{~km} / \mathrm{jam})^{2}$. Data kecepatan tersebut kemudian dicari nilai rata-ratan $(\bar{x})$ dan simpangan baku $(s)$ untuk melakukan perhitungan $\mathrm{t}_{\text {hitung. Salah satu }}$ contoh perhitungan nilai rata-rata $(\bar{x})$ untuk nilai rata-rata $\mathrm{x}_{1}\left(\overline{x_{1}}\right)$ sebagai berikut:

$$
\overline{x_{1}}=\frac{\sum_{i=1}^{n} x_{1}}{n}=\frac{483.53 \mathrm{~km} / \mathrm{jam}}{10}=48.353 \mathrm{~km} / \mathrm{jam} .
$$


Untuk perhitungan simpangan baku $(s)$ sebagai berikut:

$s_{1}=\sqrt{\frac{n \sum_{i=1}^{n} x_{i}^{n}-\left(\sum_{i=1}^{n} x_{i}\right)^{2}}{n(n-1)}}=\sqrt{\frac{10 x 23451.19-483.53^{2}}{10 \times 9}}=2.801$

Keterangan:

$s \quad=$ simpangan baku,

$\bar{x} \quad=$ nilai rata-rata,

n $\quad=$ jumlah data,

$\mathrm{x}_{\mathrm{i}} \quad=$ nilai $\mathrm{x} \mathrm{ke}-\mathrm{i}$.

Perhitungan tersebut dilakukan kembali untuk mencari $\bar{x}_{2}, \bar{x}_{3}, s_{2}$, dan $s_{3}$. Untuk hasil perhitungan kecepatan rata-rata dan simpanagan baku dapat dilihat pada Tabel 1.

Tabel 1. Hasil Perhitungan Kecepatan rata-rata dan Simpangan baku

\begin{tabular}{lcc}
\hline \multicolumn{1}{c}{ Akondisi } & Rata-rata $(\overline{\boldsymbol{x}}) \mathbf{k m} / \mathbf{j a m}$ & Simpangan Baku $(\boldsymbol{s})$ \\
\hline Ada Halte BTS Berhenti $\left(\mathbf{x}_{\mathbf{1}}\right)$ & 48.353 & 2.801 \\
Ada Halte BTS Tidak Berhenti $\left(\mathbf{x}_{2}\right)$ & 50.617 & 3.017 \\
Tanpa Halte $\left(\mathbf{x}_{3}\right)$ & 51.555 & 2.795 \\
\hline
\end{tabular}

Sumber: Data Olahan (2017)

Keterangan:

BTS $=$ Bus Trans Semarang

Data kepadatan diambil bersamaan dengan pengambilan data arus lalu lintas dan kecepatan. Data kepadatan dilakukan dengan melihat ukuran tiap tipe jenis kendaraan yang yang berada pada segmen jalan sepanjang 50 meter. Jumlah kendaraan yang telah dihasilkan kemudian dikalibrasi dengan nilai emp. Nilai kepadatan yang didapatkan dijadikan sebagai $\mathrm{x}_{1}$ untuk kondisi ada halte Bus Trans Semarang berhenti, $\mathrm{x}_{2}$ untuk kondisi ada halte Bus Trans Semarang tidak berhenti, dan $\mathrm{x}_{3}$ untuk kondisi tanpa halte. Jumlah data (n) untuk $\mathrm{x}_{1}$ sebayak 10 , untuk $\mathrm{x}_{2}$ sebayak 80 dan untuk $x_{3}$ sebayak 90. Jumlah total kepadatan $\left(\sum_{i=1}^{n} x_{i}\right)$ untuk $\left(\sum_{i=1}^{10} x_{1}\right)$ sebayak $66.69 \mathrm{smp} / \mathrm{km}$, untuk $\left(\sum_{i=1}^{80} x_{2}\right)$ sebayak $446.00 \mathrm{smp} / \mathrm{km}$ dan untuk $\left(\sum_{i=1}^{90} x_{3}\right)$ sebayak $370.52 \mathrm{smp} / \mathrm{km}$. Jumlah total untuk kepadatan yang sudah dikuadratkan $\left(\sum_{i=1}^{n} x_{i}^{2}\right)$ untuk $\left(\sum_{i=1}^{10} x_{1}^{2}\right)$ sebayak $453.797(\mathrm{smp} / \mathrm{km})^{2}$, untuk $\left(\sum_{i=1}^{80} x_{2}^{2}\right)$ sebayak $2537.621(\mathrm{smp} / \mathrm{km})^{2}$ dan untuk $\left(\sum_{i=1}^{90} x_{3}^{2}\right)$ sebayak $1553.058(\mathrm{smp} / \mathrm{km})^{2}$. Data kepadatan tersebut kemudian dicari nilai rata-ratan $(\bar{x})$ dan simpangan baku $(s)$ untuk melakukan perhitungan $t_{\text {hitung. }}$ Salah satu contoh perhitungan nilai rata-rata $(\bar{x})$ untuk nilai rata-rata $\mathrm{x}_{1}\left(\overline{\bar{x}_{1}}\right)$ sebagai berikut:

$\overline{x_{1}}=\frac{\sum_{i=1}^{n} x_{1}}{n}=\frac{66.689}{10}=6.669 \mathrm{smp} / \mathrm{km}$.

Untuk perhitungan simpangan baku $(s)$ sebagai berikut:

$s_{1}=\sqrt{\frac{n \sum_{i=1}^{n} x_{i}^{n}-\left(\sum_{i=1}^{n} x_{i}\right)^{2}}{n(n-1)}}=\sqrt{\frac{10 x 453.797-66.689^{2}}{10 x 9}}=1,003$

Keterangan:

$s=$ simpangan baku,

$\bar{x}=$ nilai rata-rata,

$\mathrm{n}=$ jumlah data,

$\mathrm{x}_{\mathrm{i}}=$ nilai $\mathrm{x}$ ke-i.

Perhitungan tersebut dilakukan kembali untuk mencari $\bar{x}_{2}, \bar{x}_{3}, s_{2}$, dan $s_{3}$. Untuk hasil perhitungan kepadatan lalu lintas rata-rata dan simpanagan baku dapat dilihat pada Tabel 2.

Tabel 2. Hasil Perhitungan kepadatan rata-rata dan Simpangan baku

\begin{tabular}{lcc}
\multicolumn{1}{c}{ Akondisi } & Rata-rata $(\overline{\boldsymbol{x}}) \mathbf{s m p} / \mathbf{k m}$ & Simpangan Baku $(\boldsymbol{s})$ \\
\hline Ada Halte BTS Berhenti $\left(\mathbf{x}_{\mathbf{1}}\right)$ & 6.669 & 1.003 \\
Ada Halte BTS Tidak Berhenti $\left(\mathbf{x}_{2}\right)$ & 5.575 & 0.8045 \\
Tanpa Halte $\left(\mathbf{x}_{3}\right)$ & 4.117 & 0.5576 \\
\hline
\end{tabular}

Sumber: Data Olahan (2017) 
Keterangan:

BTS $=$ Bus Trans Semarang

Data arus lalu lintas digunakan untuk menghitung derajat kejenuhan. Sebelum digunakan untuk menghitung derajat kejenuhan arus lalu lintas yang didapat dalam satuan kendaraan/jam diubah kedalam smp/jam dengan cara mengkalibrasi arus lau lintas dengan nilai emp. Nilai emp yang digunakan pada kondisi jalan ada halte adalah 0.267 untuk sepeda motor, 2.733 untuk angkutan umum, 3.194 untuk Bus Trans Semarang 2.7 untuk truck, sedangkan tidak ada halte adalah 0.117 untuk sepeda motor, 1.635 untuk angkutan umum, 2.054 untuk Bus Trans Semarang, 1.536 untuk truck. Arus lalu lintas yang telah diubah kedalam smp/jam kemudian dibagi dengan kapasitas jalan. Kapasitas jalan yang digunakan untuk kondisi tidak ada halte dan Bus Trans Semarang tidak berhenti di halte sebesar 3521 smp/jam, sedangkan untuk kondisi Bus Trans Semarang berhenti di halte sebesar $2442.8 \mathrm{smp} / \mathrm{jam}$ hal ini dikarenakan adanya penyempitan ruas jalan akibat Bus Trans Semarang berhenti. Nilai derajat kejenuhan yang didapatkan dijadikan sebagai $\mathrm{x}_{1}$ untuk kondisi ada halte Bus Trans Semarang berhenti, $\mathrm{x}_{2}$ untuk kondisi ada halte Bus Trans Semarang tidak berhenti, dan $\mathrm{x}_{3}$ untuk kondisi tanpa halte. Jumlah data (n) untuk $\mathrm{x}_{1}$ sebayak 10, untuk $\mathrm{x}_{2}$ sebayak 80 dan untuk $x_{3}$ sebayak 90. Jumlah total derajat kejenuhan $\left(\sum_{i=1}^{n} x_{i}\right)$ untuk $\left(\sum_{i=1}^{10} x_{1}\right)$ sebayak 10.342, untuk $\left(\sum_{i=1}^{80} x_{2}\right)$ sebayak 53.414 dan untuk $\left(\sum_{i=1}^{90} x_{3}\right)$ sebayak 48.903. Jumlah total untuk derajat kejenuhan yang sudah dikuadratkan $\left(\sum_{i=1}^{n} x_{i}^{2}\right)$ untuk $\left(\sum_{i=1}^{10} x_{1}^{2}\right)$ sebayak 10.8202, untuk $\left(\sum_{i=1}^{80} x_{2}^{2}\right)$ sebayak 36.339 dan untuk $\left(\sum_{i=1}^{90} x_{3}^{2}\right)$ sebayak 26.9753. Data derajat kejenuhan tersebut kemudian dicari nilai rata-ratan $(\bar{x})$ dan simpangan baku $(s)$ untuk melakukan perhitungan $\mathrm{t}_{\text {hitung. }}$. Salah satu contoh perhitungan nilai rata-rata $(\bar{x})$ untuk nilai rata-rata $\mathrm{x}_{1}\left(\overline{x_{1}}\right)$ sebagai berikut:

$\overline{x_{1}}=\frac{\sum_{i=1}^{n} x_{1}}{n}=\frac{10.342}{10}=1.034$

Untuk perhitungan simpangan baku $(s)$ sebagai berikut:

$$
s_{1}=\sqrt{\frac{n \sum_{i=1}^{n} x_{i}^{n}-\left(\sum_{i=1}^{n} x_{i}\right)^{2}}{n(n-1)}}=\sqrt{\frac{10 \times 10.8202-10.342^{2}}{10 \times 9}}=1.034
$$

Keterangan:

$s$ =simpangan baku,

$\bar{x}=$ nilai rata-rata,

$\mathrm{n}=$ jumlah data,

$\mathrm{x}_{\mathrm{i}}=$ nilai $\mathrm{x}$ ke-i.

Perhitungan tersebut dilakukan kembali untuk mencari $\bar{x}_{2}, \bar{x}_{3}, s_{2}$, dan $s_{3}$. Untuk hasil perhitungan derajat kejenuhan rata-rata dan simpanagan baku dapat dilihat pada Tabel 3.

Tabel 3. Hasil Perhitungan derajat kejenuhan rata-rata dan Simpangan baku

\begin{tabular}{lcc}
\hline \multicolumn{1}{c}{ Akondisi } & Rata-rata $(\overline{\boldsymbol{x}})$ & Simpangan Baku $(\boldsymbol{s})$ \\
\hline Ada Halte BTS Berhenti $\left(\mathbf{x}_{1}\right)$ & 1.034 & 0.117 \\
Ada Halte BTS Tidak Berhenti $\left(\mathbf{x}_{2}\right)$ & 0.668 & 0.0925 \\
Tanpa Halte $\left(\mathbf{x}_{3}\right)$ & 0.543 & 0.0672 \\
\hline
\end{tabular}

Sumber: Data Olahan (2017)

Keterangan:

BTS $=$ Bus Trans Semarang

Hasil perhitungan pada Tabel 1, Tabel 2 dan Tabel 3 yang telah didapatkan kemudian dipergunakan untuk perhitungan $t_{\text {hitung. }} \mathrm{t}_{\text {hitung }}$ yang didapatkan akan digunakan untuk melakukan uji-t. Output Uji-t adalah akhir dari perhitungan yang digunakan sebagai penentuan analisis terhadap hipotesis yang akan diterima atau ditolak. Dalam hal ini hipotesis yang akan diuji adalah:

$\mathrm{H}_{0}=$ Tidak terdapat perbedaan yang signifikan antara kinerja ruas jalan yang dilengkapi Halte Bus Trans Semarang dengan yang tidak dilengkapi Halte Bus Trans Semarang.

$\mathrm{H}_{1}=$ Terdapat perbedaan yang signifikan antara kinerja ruas jalan yang dilengkapi Halte Bus Trans Semarang dengan yang tidak dilengkapi Halte Bus Trans Semarang.

Dengan pengambilan Keputusan:

a) Jika nilai $-\mathrm{t}_{\text {tabel }}<\mathrm{t}_{\text {hitung }}<\mathrm{t}_{\text {tabel }}$ maka $\mathrm{H}_{0}$ diterima

b) Jika nilai $\mathrm{t}_{\text {hitung }}<-\mathrm{t}_{\text {tabel }}$ atau $\mathrm{t}_{\text {hitung }}>\mathrm{t}_{\text {tabel }}$ maka $\mathrm{H}_{0}$ ditolak 
Perhitungan $\mathrm{t}_{\text {hitung }}$ dilakukan pada kondisi ada halte Bus Trans Semarang berhenti $\left(\mathrm{x}_{1}\right)$ dengan ada halte Bus Trans Semarang tidak berhenti $\left(\mathrm{x}_{2}\right)$, ada halte Bus Trans Semarang berhenti $\left(\mathrm{x}_{1}\right)$ dengan tanpa halte Bus Trans Semarang $\left(\mathrm{x}_{3}\right)$, dan ada halte Bus Trans Semarang tidak berhenti $\left(\mathrm{x}_{2}\right)$ dengan tanpa halte Bus Trans Semarang $\left(\mathrm{x}_{3}\right)$. Contoh perhitungan mencari $\mathrm{t}_{\text {hitung }}$ kecepatan pada kondisi ada halte Bus Trans Semarang berhenti $\left(\mathrm{x}_{1}\right)$ dengan ada halte Bus Trans Semarang tidak berhenti $\left(\mathrm{x}_{2}\right)$ sebagai berikut:

$$
\mathrm{t}_{\text {hitung }}=\frac{\overline{x_{1}}-\bar{x}_{2}}{\sqrt{\frac{s_{1}^{3}}{n_{1}}-\frac{s_{2}^{n}}{n_{1}}}}=\frac{48.353-50.617}{\sqrt{\frac{3.802}{10}-\frac{8.017}{10}}}=-2.104
$$

Data yang diperlukan untuk menghitung $\mathrm{t}_{\text {hitung }}$ tersebut adalah: kecepatan rata-rata pada kondisi ada halte Bus Trans Semarang berhenti $\left(\overline{x_{1}}\right)$, Simpangan baku pada kondisi ada halte Bus Trans Semarang berhenti $\left(s_{1}\right)$, jumlah data pada kondisi ada halte Bus Trans Semarang berhenti $\left(n_{1}\right)$, kecepatan rata-rata pada kondisi ada halte Bus Trans Semarang berhenti $\left(\overline{x_{2}}\right)$, Simpangan baku pada kondisi ada halte Bus Trans Semarang berhenti $\left(s_{2}\right)$, dan jumlah data pada kondisi ada halte Bus Trans Semarang berhenti $\left(n_{2}\right)$.

Hasil dari $t_{\text {hitung }}$ yang telah didapatkan dibandingkan dengan $t_{\text {tabel. }}$ Perhitungan tersebut dilakukan kembali untuk mencari $t_{\text {hitung }}$ pada kondisi ada halte Bus Trans Semarang berhenti $\left(\mathrm{x}_{1}\right)$ dengan tanpa halte Bus Trans Semarang $\left(\mathrm{x}_{3}\right)$, dan ada halte Bus Trans Semarang tidak berhenti $\left(\mathrm{x}_{2}\right)$ dengan tanpa halte Bus Trans Semarang $\left(\mathrm{x}_{3}\right)$. Hasil perhitungan dapat dilihat pada Tabel 4.

Tabel 4. Uji-t Kecepatan Keberadaan Halte Bus Trans Semarang

\begin{tabular}{|c|c|c|c|c|}
\hline & \multirow{2}{*}{ Kondisi } & \multicolumn{2}{|c|}{ Ada Halte } & \multirow{2}{*}{ Tanpa Halte } \\
\hline & & BTS Berhenti & BTS Tidak Berhenti & \\
\hline \multirow{2}{*}{$\frac{\pi}{2} \frac{\pi}{\pi}$} & BTS Berhenti & - & $\begin{array}{c}\mathrm{t}_{\text {hitung }}=-2.252 \\
\mathrm{t}_{\text {tabel }}=-1.991\end{array}$ & $\begin{aligned} \mathrm{t}_{\text {hitung }} & =-3.435 \\
\mathrm{t}_{\text {tabel }} & =-1.987\end{aligned}$ \\
\hline & BTS Tidak Berhenti & $\begin{array}{c}\mathrm{t}_{\text {hitung }}=2.252 \\
\mathrm{t}_{\text {tabel }}=1.991\end{array}$ & 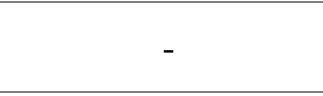 & $\begin{aligned} \mathrm{t}_{\text {hitung }} & =-2.104 \\
\mathrm{t}_{\text {tabel }} & =-1.960\end{aligned}$ \\
\hline & Tanpa Halte & $\begin{array}{c}\mathrm{t}_{\text {hitung }}=3.435 \\
\mathrm{t}_{\text {tabel }}=1.987\end{array}$ & $\begin{array}{c}\mathrm{t}_{\text {hitung }}=2.104 \\
\mathrm{t}_{\text {tabel }}=1.960\end{array}$ & - \\
\hline
\end{tabular}

Sumber: Data Olahan (2017)

Keterangan:

BTS $=$ Bus Trans Semarang.

Dari Tabel 4 dapat dilihat bahwa niali $\mathrm{t}_{\text {hitung }}<-1.991$ atau $\mathrm{t}_{\text {hitung }}>1.991$ yang berarti penolakan $\mathrm{H}_{0}$. Contoh perhitungan mencari $t_{\text {hitung }}$ kepadatan pada kondisi ada halte Bus Trans Semarang berhenti $\left(\mathrm{x}_{1}\right)$ dengan ada halte Bus Trans Semarang tidak berhenti $\left(\mathrm{x}_{2}\right)$ sebagai berikut:

$t_{\text {hitung }}=\frac{\bar{x}_{1}-\bar{x}_{2}}{\sqrt{\frac{s_{1}^{n}}{n_{1}}-\frac{s_{2}^{n}}{n_{1}}}}=\frac{6.669-5.575}{\sqrt{\frac{1.009}{10}-\frac{0.8045}{80}}}=3.943$

Data yang diperlukan untuk menghitung thitung tersebut adalah: kepadatan rata-rata pada kondisi ada halte Bus Trans Semarang berhenti $\left(\overline{x_{1}}\right)$, Simpangan baku pada kondisi ada halte Bus Trans Semarang berhenti $\left(s_{1}\right)$, jumlah data pada kondisi ada halte Bus Trans Semarang berhenti $\left(n_{1}\right)$, kepadatan rata-rata pada kondisi ada halte Bus Trans Semarang berhenti $\left(\overline{\bar{x}_{2}}\right)$, Simpangan baku pada kondisi ada halte Bus Trans Semarang berhenti $\left(s_{2}\right)$, dan jumlah data pada kondisi ada halte Bus Trans Semarang berhenti $\left(n_{2}\right)$.

Hasil dari $t_{\text {hitung }}$ yang telah didapatkan dibandingkan dengan $t_{\text {tabel. }}$. Perhitungan tersebut dilakukan kembali untuk mencari $\mathrm{t}_{\text {hitung }}$ pada kondisi ada halte Bus Trans Semarang berhenti $\left(\mathrm{x}_{1}\right)$ dengan tanpa halte Bus Trans Semarang $\left(\mathrm{x}_{3}\right)$, dan ada halte Bus Trans Semarang tidak berhenti $\left(\mathrm{x}_{2}\right)$ dengan tanpa halte Bus Trans Semarang $\left(\mathrm{x}_{3}\right)$. Hasil perhitungan dapat dilihat pada Tabel 5. 
Ari Setiawan, Pengaruh Halte Bus Trans Semarang terhadap Kinerja Lalu Lintas Pada Jalan 2/2 TT (Studi Kasus: Jalan Dokter Wahidin)

Tabel 5. Uji-t Kepadatan Keberadaan Halte Bus Trans Semarang

\begin{tabular}{|c|c|c|c|c|}
\hline \multirow{2}{*}{\multicolumn{2}{|c|}{ Kondisi }} & \multicolumn{2}{|c|}{ Ada Halte } & \multirow{2}{*}{ Tanpa Halte } \\
\hline & & BTS Berhenti & BTS Tidak Berhenti & \\
\hline \multirow{2}{*}{$\frac{\pi}{2} \frac{\pi}{\pi}$} & BTS Berhenti & 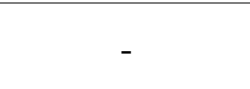 & $\begin{array}{c}\mathrm{t}_{\text {hitung }}=3.943 \\
\mathrm{t}_{\text {tabel }}=1.991\end{array}$ & $\begin{aligned} \mathrm{t}_{\text {hitung }} & =12.507 \\
\mathrm{t}_{\text {tabel }} & =1.987\end{aligned}$ \\
\hline & BTS Tidak Berhenti & $\begin{array}{c}\mathrm{t}_{\text {hitung }}=-3.943 \\
\mathrm{t}_{\text {tabel }}=-1.991\end{array}$ & तaver & $\begin{aligned} \mathrm{t}_{\text {hitung }} & =13.855 \\
\mathrm{t}_{\text {tabel }} & =1.960\end{aligned}$ \\
\hline & Tanpa Halte & $\begin{aligned} t_{\text {hitung }} & =-12.507 \\
t_{\text {tabel }} & =-1.987\end{aligned}$ & $\begin{aligned} \mathrm{t}_{\text {hitung }} & =-13.855 \\
\mathrm{t}_{\text {tabel }} & =-1.960\end{aligned}$ & 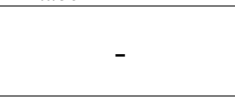 \\
\hline
\end{tabular}

Sumber: Data Olahan (2017)

Keterangan:

BTS $=$ Bus Trans Semarang.

Dari Tabel 5 dapat dilihat bahwa niali $t_{\text {hitung }}<-1.991$ atau $t_{\text {hitung }}>1.991$ yang berarti penolakan $\mathrm{H}_{0}$.

Contoh perhitungan mencari $t_{\text {hitung }}$ derajat kejenuhan pada kondisi ada halte Bus Trans Semarang berhenti $\left(\mathrm{x}_{1}\right)$ dengan ada halte Bus Trans Semarang tidak berhenti $\left(\mathrm{x}_{2}\right)$ sebagai berikut:

$\mathrm{t}_{\text {hitung }}=\frac{\bar{x}_{1}-\bar{x}_{2}}{\sqrt{\frac{s_{1}^{2}}{n_{1}}-\frac{s_{2}^{2}}{n_{1}}}}=\frac{1.034-0.668}{\sqrt{\frac{1.034}{10}-\frac{0.668}{80}}}=10.131$

Data yang diperlukan untuk menghitung $t_{\text {hitung }}$ tersebut adalah: derajat kejenuhan rata-rata pada kondisi ada halte Bus Trans Semarang berhenti $\left(\overline{x_{1}}\right)$, Simpangan baku pada kondisi ada halte Bus Trans Semarang berhenti $\left(s_{1}\right)$, jumlah data pada kondisi ada halte Bus Trans Semarang berhenti $\left(n_{1}\right)$, derajat kejenuhan rata-rata pada kondisi ada halte Bus Trans Semarang berhenti $\left(\overline{x_{2}}\right)$, Simpangan baku pada kondisi ada halte Bus Trans Semarang berhenti $\left(s_{2}\right)$, dan jumlah data pada kondisi ada halte Bus Trans Semarang berhenti $\left(n_{2}\right)$.

Hasil dari thitung yang telah didapatkan dibandingkan dengan $t_{\text {tabel. }}$. Perhitungan tersebut dilakukan kembali untuk mencari $t_{\text {hitung }}$ pada kondisi ada halte Bus Trans Semarang berhenti $\left(\mathrm{x}_{1}\right)$ dengan tanpa halte Bus Trans Semarang $\left(\mathrm{x}_{3}\right)$, dan ada halte Bus Trans Semarang tidak berhenti $\left(\mathrm{x}_{2}\right)$ dengan tanpa halte Bus Trans Semarang $\left(\mathrm{x}_{3}\right)$. Hasil perhitungan dapat dilihat pada Tabel 6.

Tabel 6. Uji-t Derajat Kejenuhan Keberadaan Halte Bus Trans Semarang

\begin{tabular}{|c|c|c|c|c|}
\hline \multirow{2}{*}{\multicolumn{2}{|c|}{ Kondisi }} & \multicolumn{2}{|c|}{ Ada Halte } & \multirow{2}{*}{ Tanpa Halte } \\
\hline & & BTS Berhenti & BTS Tidak Berhenti & \\
\hline \multirow{2}{*}{$\frac{\pi}{2} \frac{\pi}{\pi}$} & BTS Berhenti & - & $\begin{aligned} \mathrm{t}_{\text {hitung }} & =10.131 \\
\mathrm{t}_{\text {tabel }} & =1.991\end{aligned}$ & $\begin{aligned} t_{\text {hitung }} & =20.116 \\
t_{\text {tabel }} & =1.987\end{aligned}$ \\
\hline & BTS Tidak Berhenti & $\begin{aligned} \mathrm{t}_{\text {hitung }} & =-10.131 \\
\mathrm{t}_{\text {tabel }} & =-1.991\end{aligned}$ & 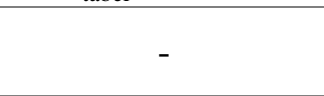 & $\begin{aligned} \mathrm{t}_{\text {hitung }} & =10.089 \\
\mathrm{t}_{\text {tabel }} & =1.960\end{aligned}$ \\
\hline & Tanpa Halte & $\begin{aligned} \mathrm{t}_{\text {hitung }} & =-20.116 \\
\mathrm{t}_{\text {tabel }} & =-1.987\end{aligned}$ & $\begin{aligned} \mathrm{t}_{\text {hitung }} & =-10.089 \\
\mathrm{t}_{\text {tabel }} & =-1.960\end{aligned}$ & (10) \\
\hline
\end{tabular}

Sumber: Data Olahan (2017)

Keterangan:

BTS $=$ Bus Trans Semarang.

Dari Tabel 6 dapat dilihat bahwa niali $\mathrm{t}_{\text {hitung }}<-1.991$ atau $\mathrm{t}_{\text {hitung }}>1.991$ yang berarti penolakan $\mathrm{H}_{0}$.

\section{Pembahasan}

Hasil perhitungan kecepatan rata-rata ada Halte saat Bus Trans Semarang berhenti $(48.353 \mathrm{~km} / \mathrm{jam})$ lebih kecil dari kecepatan rata-rata ada Halte pada saat Bus Trans Semarang tidak berhenti $(50.617 \mathrm{~km} / \mathrm{jam})$ dan kecepatan ratarata tanpa Halte Bus Trans Semarang $(51.555 \mathrm{~km} / \mathrm{jam})$. Kecepatan rata-rata ada Halte pada saat Bus Trans Semarang tidak berhenti $(50.617 \mathrm{~km} / \mathrm{jam})$ lebih kecil dari kecepatan rata-rata tanpa Halte Bus Trans Semarang $(51.555 \mathrm{~km} / \mathrm{jam})$. Hasil perhitungan kecepatan rata-rata menunjukan bahwa dengan keberadaan Halte Bus Trans kecepatan rata-rata menjadi lambat. Perlambatan kecepatan rata-rata dapat mengakibatkan penurunan kinerja lalu lintas. Nilai kepadatan rata-rata ada Halte saat Bus Trans Semarang berhenti $(6.669 \mathrm{smp} / \mathrm{km})$ lebih besar dari kepadatan rata-rata ada Halte pada saat Bus Trans Semarang tidak berhenti $(5.575 \mathrm{smp} / \mathrm{km})$ dan kepadatan rata-rata tanpa Halte Bus Trans 
Semarang (4.117 smp/km). Kepadatan rata-rata ada Halte pada saat Bus Trans Semarang tidak berhenti (5.575 smp $/ \mathrm{km}$ ) lebih besar dari kepadatan rata-rata tanpa Halte Bus Trans Semarang $(4.117 \mathrm{smp} / \mathrm{km})$. Hasil perhitungan kepadatan rata-rata menujukan bahwa dengan keberadaan Halte Bus Trans Semarang kepadatan rata-rata menjadi meningkat. Peningkatan kepadatan rata-rata dapat mengakibatkan penurunan kinerja lalu lintas. Nilai derajat kejenuhan rata-rata ada Halte saat Bus Trans Semarang berhenti (1.034) lebih besar dari derajat kejenuhan rata-rata ada Halte pada saat Bus Trans Semarang tidak berhenti (0.668) dan derajat kejenuhan rata-rata tanpa Halte Bus Trans Semarang (0.543). Derajat kejenuhan rata-rata ada Halte pada saat Bus Trans Semarang tidak berhenti (0.668) lebih besar dari derajat kejenuhan rata-rata tanpa Halte Bus Trans Semarang (0.543). Hasil perhitungan derajat kejenuhan rata-rata menujukan bahwa dengan keberadaan Halte Bus Trans Semarang derajat kejenuhan rata-rata menjadi meningkat. Peningkatan derajat kejenuhan rata-rata dapat mengakibatkan penurunan kinerja lalu lintas.

\section{SIMPULAN}

Berdasarkan hasil analisis kecepatan, kepadatan dan derajat kejenuhan maka dapat ditentukan pengaruh keberadaan Halte Bus Trans Semarang terhadap kinerja lalu lintas pada Jalan Dokter Wahidin. Pengaruh yang terjadi akibat adanya Halte Bus Trans Semarang adalah penurunan kinerja lalu lintas dan diperburuk pada saat Bus Trans Semarang berhenti di halte.

\section{Saran}

Pemerintah/instansi terkait hendaknya dalam pembuatan Halte Bus Trans Semarang perlu dilengkapi teluk bus agar kendaraan yang melintasi tidak terganggu. Perlu dilakukan penelitian lebih lanjut tentang lamanya waktu Bus Trans Semarang dalam menaikan dan menurunkan penumpang sehingga penyempitan jalan akibat bus berhenti di halte dapat dievaluasi.

\section{DAFTAR PUSTAKA}

Badan Pusat Statistik Kota Semarang (2016), Kota Semarang Dalam Angka 2016, Semarang.

https://www.google.co.id/maps/place/Semarang,+Kota+Semarang,+Jawa+Tengah/@ 7.010693,110.4023231,14z/data= !4m5!3m4!1s0x2e708b4d3f0d024d:0x1e0432b9da5cb9f2!8m2!3d-7.0051453!4d110.4381254

Kementrian Pekerjaan Umum (2014), Pedoman Kapasitas Jalan Indonesia (PKJI), Jakarta.

Khisty, C., Jotin, K. dan Lall, B. Kent (2003), Dasar-dasar Rekayasa Transportasi Jilid 1, Erlangga, Jakarta.

Koeswandono, Windarto (2007). "Pengaruh Kenderaan Tidak Bermotor Pada Jalan 2 Jalur 2 Arah Tanpa Median (Studi Kasus Jalan Parangtritis Kota Yogyakarta),” Magister Tesis. Pasca Sarjana Universitas Diponegoro, Semarang, $74 \mathrm{p}$.

Siregar, Syofian (2015), Statistik Parameterik untuk Penelitian Kuantitatif, Bumi Aksara, Jakarta. 